6-2009

\title{
Disparate Juvenile Court Outcomes for Disabled Delinquent Youth: A Social Work Call to Action
}

Christopher A. Mallett

Cleveland State University, c.a.mallett@csuohio.edu

Follow this and additional works at: https://engagedscholarship.csuohio.edu/clsowo_facpub

Part of the Criminology and Criminal Justice Commons, and the Social Work Commons How does access to this work benefit you? Let us know!

\section{Publisher's Statement}

(c)Springer Science + Business Media, LLC 2009.

\section{Recommended Citation}

Mallett, Christopher A., "Disparate Juvenile Court Outcomes for Disabled Delinquent Youth: A Social Work Call to Action" (2009). Social Work Faculty Publications. 2.

https://engagedscholarship.csuohio.edu/clsowo_facpub/2

This Article is brought to you for free and open access by the School of Social Work at EngagedScholarship@CSU. It has been accepted for inclusion in Social Work Faculty Publications by an authorized administrator of EngagedScholarship@CSU. For more information, please contact library.es@csuohio.edu. 


\title{
Disparate Juvenile Court Outcomes for Disabled Delinquent Youth: A Social Work Call to Action
}

\author{
Christopher A. Mallett
}

\begin{abstract}
Current service delivery for at-risk youth is through four separate systems: special education; mental health and substance abuse; juvenile justice; and child welfare. Many youth (and their families) are involved with more than one of these systems, making early disability identification and subsequent systems coordination paramount in leading to more successful juvenile court outcomes. This coordination is an important and prioritized public policy concern because a majority of youth (disproportionately minority) within juvenile justice populations has been identified with mental health disorders, special education disabilities, or maltreatment histories. This study of a unique sample of probation-supervised delinquent youths $(n=397)$ identifies these disabilities and their corresponding court supervision, detention, and incarceration outcomes for a 48-month period in Cuyahoga County, Ohio (greater Cleveland). Within this youth sample over $32 \%$ had a special education disability, over $39 \%$ had a mental health disorder, over $32 \%$ had a substance abuse disorder, and over $56 \%$ were victims of maltreatment. Even higher disability rates were found for those youth who were subsequently detained or incarcerated. Many of these youth had multiple disabilities (and subsequently poorer juvenile court outcomes) and were concurrently involved in more than one disability service system. Policy and client services implications are reviewed and discussed.
\end{abstract}

Keywords Delinquency - Disabilities - Outcomes - Detention · Mental health · Child welfare $\cdot$ Substance abuse $\cdot$ Special education

C. A. Mallett (ه)

School of Social Work, Cleveland State University, 2121 Euclid Avenue, \#CB324,

Cleveland, OH 44115-2214, USA

e-mail: c.a.mallett@csuohio.edu 


\section{Introduction}

Social policy and service delivery in the United States for at-risk youth is through four distinct systems: special education; mental health and substance abuse; juvenile justice; and child welfare. The special education system identifies and addresses learning and developmental disabilities through local public school districts (5.5 million elementary and high school students annually, US Census 2007; National Council of Juvenile, Family Court Judges, Juvenile Sanctions Center 2003). The mental health system includes both public and private agency providers offering treatment services for children, youth, and their families (7.6 million children and youth in 2006, National Institute of Mental Health 2006). The juvenile justice system works with youth who commit status offenses and/or crimes in both a rehabilitative and punitive framework (2.0 million cases annually, Stahl 2006; Sickmund 2006). The public child welfare system is responsible for protecting children and youth from abuse and neglect through investigations, supervision, and treatment (899,000 maltreatment cases in 2005, ACYF 2005).

Many of these youth and their families are supported by multiple systems (Burns et al. 1995; Kagendo 2001; Stroul et al. 2000; Teplin et al. 2002). Focusing on these youth with multiple risks, and disabilities, is important because early identification and systems coordination leads to cost-effective treatment and delinquency prevention (Mears and Aron 2003; Roberts 2004; Stroul et al. 2000). This paper presents important findings where identification and coordination were likely not effective and delinquent youth with disabilities had much poorer outcomes when compared to those youth without disabilities. There has been for some time a call for systemic public policy review and service delivery change to better serve this population (GAO 2003; White House Task Force for Disadvantaged Youth 2004), although comprehensive overviews are limited (Aron et al. 1996; Friedman et al. 1996; Pires 2002; Stroul and Friedman 1996).

Current disability policy trends for this population are not encouraging. Few local, state, or national organizations maintain reliable records of the service types or funding provided for youths with disabilities at risk of delinquency. Punitive policies for youthful felony offenders preclude a rehabilitative framework, even though the needs and service gaps may be greater in the juvenile justice system. Many school systems are not providing legally required disability services (Mears and Aron 2003; Roberts 2004; Stroul et al. 2000). Effective programming for youths requires overcoming systemic barriers and improving intersystem collaboration. Because of conflicting orientations, resources, or disparate federal disability definitions (ABA 2006; Aron et al. 1996), the result today is "an inefficiently interconnected set of systems that fails to provide disability related services for youth who need them" (Mears and Aron 2003, p. viii).

These trends are particularly problematic for the juvenile courts which work with a population that is disproportionately represented by youths with disabilities and minority youth (Mears and Aron 2003; National Institute of Justice 2003). Within juvenile detention centers and incarceration facilities, the youth population has high prevalence rates of mental health disorders (40-90\%) (Boesky 2002; Lexcon and Redding 2000; McCabe et al. 2002; Plisaka et al. 2000; Teplin et al. 2002, 2006; 
Wasserman et al. 2002); substance abuse disorders (37-73\%) (Aaron et al. 2001; Archwarnety and Katsiyannis 1998; Brunelle et al. 2000; National Institute of Justice 2003; Teplin et al. 2002, 2006); special education disabilities, primarily learning disabilities (33-41\%) (Burrell and Warboys 2000; Malmgren et al. 1999; Mears and Aron 2003; National Council on Disability 2002); and maltreatment (child welfare) histories (40-60\%) (Farrington 1998; Lemmon 2006; Ryan and Testa 2005; Stewart et al. 2002; Wasserman and Seracini 2001). What is absent in the literature to date are reviews of these juvenile offender populations who are community supervised and not held in facilities. In other words, research knowledge is currently limited to detained and incarcerated offenders, who make up a small percentage of youth who are on probation at any given time (Stahl 2006). A few researchers have addressed this gap and found concurrent mental health and substance abuse disabilities for delinquent populations, some with past family child welfare system involvement (Garland et al. 2001; Herz et al. 2006; Mallett 2008; Ryan and Testa 2005).

A number of recent federal policy initiatives have (with undetermined outcomes to date) focused attention on coordinating and prioritizing effective service delivery to assist these youths. The Federal Youth Coordination Act $^{1}$ establishes a Federal Youth Development Council to improve communication among federal agencies serving at-risk youth, assess needs, assist in goal attainment, and establish best practices for service improvement. The Younger Americans $\mathrm{Act}^{2}$ would establish within the Executive Office of the President an Office of National Youth Policy. This office, along with an established Council on National Youth Policy, would be empowered to resolve administrative and programmatic conflicts between and among federal programs and the linkages to state and local service delivery. In similar efforts, the US Office of Juvenile Justice and Delinquency Prevention (OJJDP) is currently pilot-testing the Court Coordination Program, exploring whether a coordinator within the juvenile court can leverage and improve crosssystem agency services for youth who are multiply-disabled and court-involved.

This research study supports the need for these federal policy initiatives and coordination efforts by finding high delinquent youth disability rates, multiple service delivery system utilization, and disparate juvenile court outcomes for offenders with disabilities in Ohio's largest county-Cuyahoga (Cleveland). This study is important because it provides findings from a unique youth sample-a population of juvenile offenders (with and without disabilities) who are on community-based probation supervision, not just those detained or incarcerated. This study's methodology is reviewed first. Second, disability epidemiology and outcome findings are presented for this population. Third, in light of these findings, public policy implications and recommendations are set forth.

\footnotetext{
${ }^{1}$ Introduced February 16, 2005, by Rep. Tom Osborne, Senator Norm Coleman, and Rep. Donald Payne (H.R. 856/S. 409). Passed the House of Representatives on November 17th, 2005; passed the Senate on September 20, 2006, and signed by President G. W. Bush on October 17, 2006. Can be accessed at http://thomas.loc.gov.

2 Senate Bill 3085 (106th Congress) had been "stuck", and ultimately "died", in the Health, Education, Labor, and Pensions Committee at the end of the 106th Congressional session. The bill was co-sponsored by Senators Cleland, Kennedy, Landrieu, and Murray. Can be accessed at http://thomas.loc.gov.
} 


\section{Methodology}

\section{Research Questions}

Research to date has found and emphasized that disability identification, treatment, and diversion from punitive outcomes helps many youth involved in the juvenile justice system discontinue their offending and significantly decreases recidivism (American Bar Association Juvenile Justice Center 2007; Mears and Aron 2003). This study was undertaken to continue research epidemiology identifying these disabilities within a population of already at-risk youth-those involved in the juvenile justice system. To do this, two research questions were asked in this study. One, how many adjudicated delinquent youth had identified disabilities (mental health, substance abuse, special education, and maltreatment histories), and were there different prevalence rates for youth held in correctional facilities? Two, what were the probation outcomes for incarcerated youth compared to non-incarcerated youth, and were there outcome differences when reviewing youth with multiple disabilities?

\section{Research Design and Sample}

This study utilized a random sample $(n=397)$ of all adjudicated delinquent youth who received probation supervision from the Cuyahoga County, Ohio, Juvenile Court from 2003 to 2006 . The population of delinquent youth for calendar years 2003, 2004, 2005, and $2006(N=16,110)$ was assigned sequential file numbers and a simple, random technique was calculated to identify the sample (Urbaniak and Plous 2007). The sampled youth and family histories were retrospectively reviewed identifying disability rates, disability service delivery systems utilization, and court probation outcomes for this 48-month period (January 2003-December 2006). Variables measured included the youth's age; mental health and substance abuse diagnoses; substance abuse, mental health, special education, and child welfare system service involvement; special education disabilities; delinquency offenses; probation services; placement in detention and incarceration facilities; length of probation supervision; and probation closure without detention or recidivism.

This retrospective, archival design utilized the following documents: probation supervision case files; full juvenile court arrest, offense, and disposition histories; court records of family child welfare system involvement; mental health/substance abuse reports (court and agency authored); assessments (diagnostic assessments, social histories, and/or psychological/psychiatric evaluations); and special education individualized education plans. All files reviewed were of public record and used with permission from the juvenile court; no human subjects were involved in this study.

Measurements

\section{Special Education/Developmental Disabilities}

The four federally recognized special education categories are severely behaviorally handicapped, learning disabled, severely emotionally disturbed, and developmentally 
handicapped. ${ }^{3}$ Developmental disabilities is a separate disability system within the Administration on Children and Families in the US Department of Health and Human Services. Because almost all children and adolescents who would qualify for developmental disabilities access services through the special education system, these two disability categories were combined for this study's measurement. Special education/developmental disabilities were measured by documentation of the youths' school districts individual education plans (IEP's).

\section{Mental Health and Substance Abuse Disorders}

Mental health and substance abuse disorders were identified through psychiatric diagnosis utilizing the American Psychiatric Association's (APA) Diagnostic and Statistical Manual of Mental Disorders-IV (APA 2000), measured using a youth's documented diagnostic assessment. These disorders included conduct disorder, oppositional defiant disorder, affective disorders (depression, dysthmia, and mood), bipolar, attention-deficit hyperactivity disorder, substance (alcohol and drug) disorders, and phobias.

\section{Child Welfare (Maltreatment)}

In Ohio, there are four defined maltreatment types used within the child welfare system: physical abuse, sexual abuse, neglect, and emotional neglect. Child welfare involvement (maltreatment) was documented through substantiated findings of the youths' child welfare etiologies. ${ }^{4}$

\section{Delinquent Youth Epidemiology and Juvenile Court Outcomes}

A majority of these youth were older (15 years of age at initial probation intake), minority (70.6\% African-American; 25.1\% Caucasian; and 4.3\% HispanicAmerican), male (79.8\%), who lived in poor (56.4\% below the poverty line), single-parent homes (72.4\%). Youth with special education disabilities had fewer delinquency offenses (4.0) than youth with mental health or substance abuse disorders (6.0), but equal numbers of probation services (3.0 and 3.1, respectively).

\footnotetext{
320 U.S.C. $\$ 1401(26)($ A-C); 20 U.S.C. $\$ 1401(3) ; 34$ C.F.R. $\$ 222.50$. The Individuals with Disabilities Education Act (IDEA 2004) and Education for All Handicapped Children Act (1974) define disability as a child/adolescent with mental retardation, hearing impairments, visual impairments (including blindness), serious emotional disturbance, orthopedic impairments, autism, traumatic brain injury, other health impairments, or specific learning disabilities.

4 O.R.C. \$2151.031; O.R.C. \$2151.03(A); O.R.C. \$2151.031; 2907.01; 2919.22. Child welfare investigations have three possible outcomes: substantiated; indicated; or unsubstantiated findings.
} 
Youth Disability Prevalence Rates

The findings are presented in two groups. First, the full sample of youth on probation $(n=397)$; and, second, a sample subset of the youth on probation who experienced a detention center placement or state facility incarceration $(n=123)$.

Many of the youth on probation supervision had disabilities (see Table 1): $32.5 \%$ had a special education disability; $39.8 \%$ had a mental health disorder; $32.4 \%$ had a substance abuse disorder; and $56.2 \%$ had been a victim of past maltreatment. Of particular note was that higher percentages of this group who were detained or incarcerated had special education disabilities (39.4\%), mental health disorders $(68.2 \%)$, and substance abuse disorders $(49.5 \%)$. These findings comport with other research studies of incarcerated offenders in different jurisdictions (Aaron et al. 2001; Lemmon 2006; Mears and Aron 2003; National Council on Disability 2002; National Institute of Justice 2003; Ryan and Testa 2005; Teplin et al. 2002, 2006). Many more youth who were under juvenile court supervision had these disabilities compared to the general youth population (ACYF 2005; Center for Mental Health Services 2004; National Mental Health Association 2004; US Department of Education 2004; US Department of Health and Human Services 2006).

\section{Disabilities and Court Outcomes}

These youth were multiply-disabled and used numerous systems concurrently to meet their needs (see Table 2). More than 50\% of the delinquent youth were involved with either the mental health or substance abuse system, and more than $40 \%$ of these youth were also involved with the special education system. These

Table 1 Youth disability prevalence rates

\begin{tabular}{|c|c|c|c|c|}
\hline Disability types & $\begin{array}{l}\text { Cuyahoga County, } \\
\text { Ohio, juvenile } \\
\text { probation population } \\
(n=397)\end{array}$ & $\begin{array}{l}\text { Cuyahoga County, } \\
\text { Ohio, detained or } \\
\text { incarcerated subset } \\
(\%)(n=123)\end{array}$ & $\begin{array}{l}\text { Other incarcerated } \\
\text { juvenile offender } \\
\text { population studies } \\
(\%)\end{array}$ & $\begin{array}{l}\text { The general } \\
\text { youth } \\
\text { population } \\
(\%)\end{array}$ \\
\hline $\begin{array}{l}\text { Special } \\
\quad \text { education } \\
\text { disabilities }\end{array}$ & 32.5 & 39.4 & $33.0-41.0$ & $4.0-10.0$ \\
\hline $\begin{array}{l}\text { Mental } \\
\text { health } \\
\text { disorders }\end{array}$ & 39.8 & 68.2 & $40.0-90.0$ & $9.0-16.0$ \\
\hline $\begin{array}{l}\text { Substance } \\
\text { abuse } \\
\text { disorders }\end{array}$ & 32.4 & 49.5 & $37.0-73.0$ & $5.4-6.1$ \\
\hline $\begin{array}{c}\text { Maltreatment } \\
\text { histories }\end{array}$ & $\begin{array}{l}56.2 \\
\text { Maltreatment type: } \\
\text { Neglect-69.0 } \\
\text { Physical abuse-21.5 } \\
\text { Sexual abuse-8.5 }\end{array}$ & 42.2 & $40.0-60.0$ & 1.4 \\
\hline
\end{tabular}


Table 2 Disability service utilization rates and court outcomes (2003-2006)

\begin{tabular}{llll}
\hline $\begin{array}{l}\text { Concurrent utilization of } \\
\text { disability systems } \\
(2003-2006)\end{array}$ & $\begin{array}{l}\text { Cuyahoga County, } \\
\text { Ohio, juvenile } \\
\text { probation population } \\
(\%)(n=397)\end{array}$ & $\begin{array}{l}\text { Successful probation } \\
\text { completion-within } \\
12 \text { months without re- } \\
\text { offending or placement }(\%)\end{array}$ & $\begin{array}{l}\text { Probation } \\
\text { supervision } \\
\text { greater than } \\
12 \text { months (\%) }\end{array}$ \\
\hline $\begin{array}{l}\text { 1 System } \\
\text { (juvenile justice only-no } \\
\text { identified disability) }\end{array}$ & $\begin{array}{l}36.5 \text { (full sample) } \\
32.4 \text { (subset) }\end{array}$ & 63.7 & 15.2 \\
$\begin{array}{l}2 \text { Systems } \\
\text { (juvenile justice and mental } \\
\text { health/substance abuse) }\end{array}$ & $\begin{array}{l}55.1 \text { (full sample) } \\
62.0 \text { (subset) }\end{array}$ & 34.4 & 19.4 \\
$\begin{array}{l}3 \text { Systems } \\
\text { (juvenile justice; mental } \\
\text { health/substance abuse; and } \\
\text { special education) }\end{array}$ & $\begin{array}{l}42.3 \text { (full sample) } \\
\begin{array}{l}5 \text { Systems } \\
\text { (juvenile justice; mental }\end{array}\end{array}$ & 27.7 & 24.1 \\
$\begin{array}{l}\text { health/substance abuse; } \\
\text { special education; and child } \\
\text { welfare) }\end{array}$ & 9.4 (full sample) & 21.0 & 8.4 \\
\hline
\end{tabular}

disability system involvement rates were even higher for detained or incarcerated youth within this delinquent population: a majority had both a mental health or substance abuse disorder and a special education disability. Youth who were involved with more disability systems had fewer successful probation outcomes and higher incarceration and detention rates. More poignantly, youths without these disabilities were twice as likely to have completed probation successfully without a court placement.

\section{Discussion}

This study found that youth on juvenile court probation needed multiple social policy systems to meet their disability needs. This is a unique finding in that previous research on delinquent populations and disability epidemiology included only detained or incarcerated offenders. Here, the findings are much broader, including the full probation population, community-supervised as well as detained. A majority of youth and their families accessed and concurrently utilized disability services from two or more systems, suggesting that one system was not sufficient for the multi-dimensional difficulties of this at-risk population. While multiple interventions, through the use of services, may decrease the utilization of secure institutions, of concern is that over half of these detained and incarcerated youth had multiple disabilities (mental health or substance abuse, and special education). It is unclear how well the court addressed these youths' needs in light of some poorer probation outcomes. When these youth re-enter the community from placement facilities, they continue on probation supervision. Efforts to successfully reintegrate 
these youth and families and to coordinate disability and social work care are crucial in decreasing recidivism (Brenden and Tollet 1999; Holman and Ziedenberg 2006; Mears and Aron 2003).

These Cuyahoga County Juvenile Court findings are similar to other researched jurisdictions on three outcomes: many supervised juvenile offenders are placed into detention centers or incarcerated; many of these incarcerated youth have disabilities; and a disproportionate number of these incarcerated youth are minority (National Institute of Justice 2003; Poe-Yamagata and Jones 2000). On any given day in this country, 54,500 youth are held in detention centers or incarceration facilities nationwide, with a majority having at least one mental health, substance abuse, or special education disability (Census 2003; Lemmon 2006; National Institute of Justice 2003; Sickmund et al. 2004; Teplin et al. 2006). Concern over this situation was the significant factor in the recent passage of the Federal Second Chance Act of 2007. This legislation links Federal funding for secure custody reentry demonstration projects to service coordination for the youth and family, in that extensive evidence of collaboration with agencies overseeing health, child welfare, education, substance abuse, and employment must be demonstrated.

Beyond re-entry efforts, a focus on early disability identification and social work prevention programs should be pursued for such programs have been found to be effective in reducing delinquency and minimizing other risks for these youth (Klitzner et al. 1991; Mears and Aron 2003; Roberts 2004; Stroul et al. 2000). Additionally, uncoordinated youth disability services among these delivery systems should be identified with a focus on collaboration and increased efficacy. This unique study population and review found a majority of youth on probation had also concurrently accessed the mental health, substance abuse, and/or special education systems, a finding identified by a limited number of other researchers (Garland et al. 2001; Herz et al. 2006). There is a need for mental health and substance abuse screenings/assessments for first-time offenders and for probated youth, particularly those at higher risk for detention and incarceration. This identification might be known or identified within other disability systems, but coordinated information sharing and planning was not apparent for these studied youth. The youth involved with this juvenile court and other disability systems could greatly benefit from improved service delivery, helping to minimize delinquency and harmful incarcerations.

An exception to this lack of coordination evidence among systems in this study may be seen in that youth who were multiply-disabled and involved (or re-involved) with children's services were infrequently detained or incarcerated. However, often times when the court referred the case, probation supervision ended, raising the question of whether this was coordination or deference. Further explanations of this outcome cannot be identified through this study's methodology. Additional study limitations are that these results are for only one, large, urban juvenile court jurisdiction, and cumulative disability epidemiology findings for this population are limited. Studies of this type also have limited external validity, and utilization of existing records can lead to measurement reliability and validity concerns. To make proactive and effective public policy decisions, representative state and national 
studies should be undertaken to clearly identify the magnitude, dimensions, service delivery needs, and outcomes for delinquent youths with disabilities.

There is increasing federal, and subsequently local, policy focus on the need to coordinate systems and subsequent service delivery for delinquent youths, and reentering juvenile offenders, with disabilities. These efforts are clearly supported by the disability prevalence rates and disparate juvenile court outcomes from Cuyahoga County (Cleveland), Ohio. If these findings continue to be the outcome, broad system changes should include early assessments, disability identification, and increased diversion and systems coordination. To be more accountable in working with this population, federal, state, and local service delivery systems must vastly improve current efforts through the implementation of effective collaborations and programs.

\section{References}

Aaron, G. A., Browns, S. A., Hough, R. L., Garland, A. F., \& Wood, P. A. (2001). Prevalence of adolescent substance use disorders across five sectors of care. Journal of the American Academy of Child and Adolescent Psychiatry, 40(4), 419-426. doi:10.1097/00004583-200104000-00010.

Administration on Children, Youth, and Families (ACYF). (2005). Child maltreatment. Washington, DC: US Department of Health and Human Services, from http://faq.acf.hhs.gov/cgiin/acfrightnow. cfg/php/enduser/std_adp.php?p_sid=uKT6q7bi\&p_lva=\&p_faqid=68\&p_created=1001610478\&p_ $\mathrm{sp}=\mathrm{cF} 9 \mathrm{zcmNoPTEmcF9ncmlkc29ydD0mcF9yb3dfY250PTEzJnBfc2VhcmNoX3RleHQ9JnBfc2}$ VhcmNoX3R5cGU9MyZwX2NhdF9sdmwxPTEwJnBfY2F0X2x2bDI9MzAmcF9zb3J0X2J5PWR mbHQmcF9wYWdlPTE*\&p_li. Accessed 1 May 2007.

American Bar Association. (2006). ABA presidential initiative for youth at risk. From http://www.abanet. org/initiatives/youthatrisk.

American Bar Association Juvenile Justice Center. (2007). Available at http://www.abanet.org/dch/ committee.cfm?com=CR200000. Accessed 5 Aug 2008.

American Psychiatric Association. (2000). The diagnostic and statistical manual of mental disorders-IVtext revision. Washington, DC: American Psychiatric Association Press.

Archwarnety, T., \& Katsiyannis, A. (1998). Factors related to recidivism among delinquent females at a state correctional facility. Journal of Child and Family Studies, 7(1), 59-67. doi:10.1023/A:102 2960013342.

Aron, L., Loprest, P., \& Steuerle, E. (1996). Serving children with disabilities: A systemic look at the programs. Washington, DC: The Urban Institute Press.

Boesky, L. M. (2002). Juvenile offenders with mental health disorders: Who are they and what do we do with them? (p. 4). Washington, DC: American Correctional Association.

Brenden, B. B., \& Tollet, C. L. (1999). A study of recidivism of serious and persistent offenders among Adolescents. Journal of Criminal Justice, 27(2), 111-126. doi:10.1016/S0047-2352(98)00051-8.

Brunelle, H., Brochu, S., \& Cousineau, M. (2000). Drug-crime relations among drug-consuming juvenile delinquents: A tripartite model and more. Contemporary Drug Problems, 27(4), 835-867.

Burns, B., Costello, J., Angold, A., Tweed, D., Stangl, D., Farmer, E., et al. (1995). Children's mental health service use across service sectors. Health Affairs, 14(3), 147-159. doi:10.1377/hlthaff.14. 3.147 .

Burrell, S., \& Warboys, L. (2000). Special education and the juvenile justice system. Washington, DC: Department of Justice Office of Juvenile Justice and Delinquency Prevention.

Center for Mental Health Services. (2004). Mental health, United States. Washington, DC: US Department of Health and Human Services, Public Health Service.

Cuyahoga County Court of Common Pleas (2003, 2004, 2005, 2006). Annual reports. From http:// cuyahogacounty.us/Juvenile/annualreport.htm.

Farrington, D. F. (1998). Predictors, causes, and correlates of male youth violence. In M. Tonry \& M. Moore (Eds.), Youth violence (pp. 421-475). Chicago: University of Chicago Press. 
Friedman, R. M., Kutash, K., \& Duchnowski, A. J. (1996). The population of concern: Defining the issues. In B. Stroul (Ed.), Children's mental health (pp. 69-96). USA: Brooks Publishing.

Garland, A., Hough, R. L., McCabe, K. M., Yeh, M., Wood, P. A., \& Aarons, G. A. (2001). Prevalence of psychiatric disorders in youths across five sectors of care. Journal of the American Academy of Child and Adolescent Psychiatry, 40(4), 409-418. doi:10.1097/00004583-200104000-00009.

General Accountability Office. (April 21, 2003). Child welfare and juvenile justice: Federal agencies could ply a stronger role in helping states reduce the number of children placed solely to obtain mental health services, Report \#03-397, Washington, DC.

Herz, D., Krinsky, M., \& Ryan, J. (2006). Improving system responses to crossover youth: The role of research and practice partnerships. The Link: Child Welfare League of America, 5(1), 1-12.

Holman, B., \& Ziedenberg, J. (2006). The dangers of detention: The impact of incarcerating youth in detention and other secure congregate facilities. Baltimore MD: Annie E Casey Foundation.

Individuals with Disabilities in Education Act. (2004 reauthorization). Available at http://frwebgate. access.gpo.gov/cgi-bin/getdoc.cgi?dbname=108_cong_public_laws\&docid=f:pub1446.108. Accessed 5 Aug 2008.

Kagendo, M. (2001). Policied identities: Children with disabilities. Educational Studies, 32(3), 289-300.

Klitzner, M., Fisher, D., Stewart, K., \& Gilbert, S. (1991). Report to the Robert Wood Johnson Foundation on strategies for early intervention with children and youth to avoid abuse of addictive substances. Bethesda, MD: Pacific Institute for Research and Evaluation, from http://www.rwjf.org/ files/publications/books/2005/chapter_07.pdf. Accessed 25 June 2007.

Lemmon, J. H. (2006). Effects of maltreatment recurrence and child welfare services on dimensions of delinquency. Criminal Justice Review, 31(1), 5-32. doi:10.1177/0734016806287945.

Lexcon, F. \& Redding, R. E. (2000). Mental health needs of juvenile offenders. Juvenile Correctional Mental Health Report, 3(1), 1, 2, 8-16.

Mallett, C. (2008). The disconnect between delinquent youths with mental health and special education disabilities and juvenile court outcomes. Corrections Compendium, 33(5), 1-23.

Malmgren, K., Abbott, R., \& Hawkins, D. (1999). Learning disability and delinquency: Rethinking the "link". Journal of Learning Disabilities, 32(2), 194-200. doi:10.1177/002221949903200301.

McCabe, K. M., Lansing, A. E., Garland, A., \& Hough, R. (2002). Gender differences in psychopathology, functional impairment, and familial risk factors among adjudicated delinquents. Journal of the American Academy of Child and Adolescent Psychiatry, 41, 860-867. doi:10.1097/ 00004583-200207000-00020.

Mears, D., \& Aron, L. (2003). Addressing the needs of youth with disabilities in the juvenile justice system: The current state of knowledge. Washington, DC: The Urban Institute, from http://www. urban.org/publications/410885.html. Accessed 10 Sept 2007.

National Council of Juvenile, Family Court Judges, Juvenile Sanctions Center. (2003). Graduated sanctions for juvenile offenders: A program model and planning guide. Reno, NV: University of Nevada.

National Council on Disability. (2002). National disability policy: A progress report. Washington, DC: National council on disability. December, from http://www.ncd.gov/newsroom/publications/2003/ progressreport_final.htm. Accessed 14 Sept 2007.

National Institute of Justice. (2003). Arrestee drug abuse monitoring: Annual report. From http://www.ncjrs.org/pdffiles1/nij/103013.pdf. Accessed 15 Sept 2007.

National Institute of Mental Health. (2006). The numbers count. From http://www.nimh.nih.gov/publicat/ numbers.cfm. Accessed 20 Sept 2007.

National Mental Health Association. (2004). Prevalence of mental disorders among children in the juvenile justice system. From http://www.nmha.org/children/justjuv/prevalence.cfm. Accessed 15 Sept 2007.

Office of Juvenile Justice and Delinquency Prevention. (2003). Census of juveniles in residential placement databook.Washington, DC: Office of Juvenile Justice and Delinquency Prevention, from http://ojjdp.ncjrs.org/ojstatbb/cjrp/asp/State_Adj.asp.

Pires, S. (2002). Building systems of care: A primer. Washington, DC: Human Services Collaboration, SAMSHA.

Plisaka, S. R., Sherman, J. O., Barow, M. V., \& Irick, S. (2000). Affective disorder in juvenile offenders: A preliminary study. The American Journal of Psychiatry, 157, 130-132.

Poe-Yamagata, E., \& Jones, M. (2000). And justice for some. Washington, DC: Building Blocks for Youth. From http://www.buildingblocksforyouth.org/justiceforsome/. Accessed 20 Sept 2007.

Roberts, A. R. (2004). Juvenile justice sourcebook: Past, present, and future. USA: Oxford Press. 
Ryan, J. P., \& Testa, M. F. (2005). Child maltreatment and juvenile delinquency: Investigating the role of placement and placement instability. Children and Youth Services Review, 27, 227-249. doi: 10.1016/j.childyouth.2004.05.007.

Sickmund, M. (2006). Juvenile residential facility census, 2002: Selected findings. Washington, DC: Juvenile Offenders and Victims National Report Series, U.S. Department of Justice, Office of Justice Programs, Office of Juvenile Justice and Delinquency Prevention. (June).

Sickmund, M., Sladky, T. J., \& Kang, W. (2004). Census of juveniles in residential placement databook. From http://www.ojjdp.ncjrs.org/ojstatbb/cjrp/. Accessed 20 Sept 2007.

Stahl, A. L. (2006). Delinquency cases in juvenile court, 2002. Washington, DC: US Department of Justice, Office of Juvenile Justice and Delinquency Prevention. From http://www.ncjrs.gov/pdf files1/ojjdp/fs200602.pdf.

Stewart, A., Dennson, S., \& Waterson, E. (2002). Pathways from child maltreatment to juvenile offending. Washington, DC: Criminology Research Council.

Stroul, B., \& Friedman, R. M. (1996). The system of care concept and philosophy. In B. Stroul (Ed.), Children's mental health (pp. 3-21). USA: Brooks Publishing.

Stroul, B., Pires, S., \& Armstrong, M. (2000). Health care reform tracking project. USA: Louis de la Parte Florida Mental Health Institute, University of South Florida.

Teplin, L., Abram, K., McClelland, G., Dulcan, M., \& Mericle, A. (2002). Psychiatric disorders in youth in juvenile detention. Archives of General Psychiatry, 59, 1133-1143. doi:10.1001/archpsyc.59. 12.1133 .

Teplin, L., Abram, K., McClelland, G., Mericle, A., Dulcan, M., \& Washburn, D. (2006). Psychiatric disorders of youth in detention. Washington, DC: Office of Juvenile Justice and Delinquency Prevention, Juvenile Justice Bulletin, Office of Justice Programs. (April).

Urbaniak, G. C., \& Plous, S. (2007). Research randomizer. Social Psychology Network, from http://www. randomizer.org/form.htm.

US Department of Education. Office of Special Education Programs (OSEP) (2004). Data analysis system, Table AA5, from http://www.ed.gov/about/reports/annual/osep/2003/25th-vol-1-sec-1.pdf. Accessed 20 Aug 2007.

US Department of Health and Human Services. (2006). Results from the 2005 national survey on drug abuse and health. Substance Abuse and Mental Health Services Administration, Office of Applied Studies, from http://www.drugabusestatistics.samhsa.gov/NSDUH/2k5NSDUH/2k5results.htm. Accessed 15 June 2008.

US Census Bureau. (2007). Back to school, 2007-2008. From http://www.census.gov/PressRelease/www/ releases/archives/facts_for_features_special_editions/010218.html. Accessed 30 Aug 2008.

Wasserman, G. A., McReynolds, L. S., Lucas, C. P., Fisher, P., \& Santos, L. (2002). The voice DISC-IV with incarcerated male youths: Prevalence of disorder. Journal of the American Academy of Child and Adolescent Psychiatry, 41, 314-321. doi:10.1097/00004583-200203000-00011.

Wasserman, G. A., \& Seracini, A. G. (2001). Family risk factors and interventions. In R. Loeber \& D. P. Farrington (Eds.), Child delinquents: Development, intervention, and service needs (pp. 165-189). Thousand Oaks, CA: Sage Publications.

White House Task Force for Disadvantaged Youth. (2004). Final report to President Bush. From http://www.youthcoordinationact.org/nydic/policy/fycs.htm. Accessed 17 July 2007. 